\begin{tabular}{c} 
Volume and Issues Obtainable at Center for Sustainability Research and Consultancy \\
Journal of Accounting and Finance in Emerging Economies \\
ISSN: 2519-0318ISSN (E) 2518-8488 \\
Volume 4: Issue 1June 2018 \\
CSRᄃ \\
Journal homepage: www.publishing.globalcsrc.org/jafee \\
\hline
\end{tabular}

\title{
How Companies Value Stock Prices After Going Public: Evidence from Emerging Pakistan Economy
}

\author{
${ }^{1}$ Muhammad Aamir, ${ }^{2}$ Hafiz Muhammad Nadeem, ${ }^{3}$ Khawer Naheed, ${ }^{4}$ Allah Bakhsh Khan \\ ${ }^{1}$ Assistant Professor, Department of Commerce, Bahauddin Zakariya University, Multan, Pakistan. \\ maamirbzu@yahoo.com \\ ${ }^{2}$ Department of Commerce, Bahauddin Zakariya University, Multan, Pakistan. \\ hafiznadeem203@gmail.com \\ ${ }^{3}$ Assistant professor, Department of Commerce, Bahauddin Zakariya University, Multan, Pakistan. \\ khawarnaheed@bzu.edu.com \\ ${ }^{4}$ Assistant professor, Department of Commerce, Bahauddin Zakariya University, Multan, Pakistan \\ abkhan@bzu.edu.com
}

\begin{tabular}{l}
\hline ARTICLEDETAILS \\
\hline History \\
Revised format: May 2018 \\
Available online: June 2018 \\
\\
\hline Keywords \\
Efficient Market Hypothesis, \\
Initial Public Offering, Karachi \\
Stock Exchange, Market \\
Return, Investment.
\end{tabular}

JEL Classification:

A10,D70,O24

\begin{abstract}
The purpose of this study is to estimate the accuracy and authenticity of valuation methods used by underwriters to set preliminary offer price. This study uses complete universe of all newly listed companies during 2000 to 2015 on Pakistan Stock Exchange. We analyzed the determinants of the Initial Public Offering (IPOs) by comparing the ex-ante and ex-post characteristics of IPOs firms. Binary logistic model was used for evaluation of variables. Results revealed that underwriters use four different valuation methods to set IPO preliminary offer price namely as dividend discount model (DDM), discounted cash flow method (DCF), peer groups multiple (MULT) and economic valuation method (EVA). This study used Binary Logistic Regression model to estimate the accuracy and authenticity of these valuation methods. Results of this study can help the portfolio managers for constructing their effective portfolio strategies. This study also helps to highly levered firms to get cheaper long term capital by going public. This study is also important for underwriters to counter check their valuation patterns for IPO firms.
\end{abstract}

(C) 2018 The authors, under a Creative Commons Attribution-Non Commercial 4.0

Corresponding author's email address: hafiznadeem203@gmail.com

Recommended citation: Aamir, M, Nadeem, H.M., Naheed, K., Akhtar, A., (2018). How Companies Value Stock Prices After Going Public: Evidence from Emerging Pakistan Economy. Journal of Accounting and Finance in Emerging Economies, 4(1) 29-38

DOI: $10.26710 /$ jafee.v4i1.338

\section{Introduction}

It is said that an initial public offering constitutes hurdles relating price discovery (Engelen \& Van Essen, 2010). It is not sure in market relating quality of initial public offering of firms while the firms that issue shares unaware about demand of their shares. Issuer firms therefore entrust the decision of offer price for investors that underwrites the initial public offering (Bancel \& Mittoo, 2009). Underwriters have muscular incentives to build their repute as expertise of valuation and endorse that offer price reflects 
basic value. In our empirical analysis, we will elaborate how underwriters can make more authenticated valuation through specific valuation methods.

Dividend discount model is usually used in so many cases. The contemporary research elaborates that underwriters select the valuation method on the basis of firm characteristics. Modern literature usually give the priority to dividend discount model to check the values of those firms which go public when overall previous market returns are so low and when companies take a decision about their future earnings large portion as dividend. The weights which were assigned by the underwriters to the value estimates to their fair values also depend on the different factors of the firm and overall stock market position.

Penman (2001) described that investment is considered as loss in dividend discounted cash flow method and freely cash flows totally fail to recognize the value that does not include the cash flows. In addition, highly growing firms keep their profits as savings rather than paying dividend. It is difficult for large firms to value firms because large part of their profit comes from growth options. Dividend discount model and discounted cash flow methods cannot incorporate the value of these growth opportunities. Bancel \& Mittoo (2009) elaborate that many financial analysis view dividend discount model more useful to value stable, high dividend paying stock. They predict that underwriters most likely to use dividend discount model when setting the fair value estimates for firm.

\section{Literature Review}

Deloof et al (2009) revealed that although the underwriters use different methods to value an IPO but DCF is the most appropriate method for IPO valuation. Their findings suggest that use of dividend discount model would result in underestimating the value of an IPO, while DCF produced unbiased results. The results also demonstrated that final offer price of an IPO set by an underwriter is closer to the stock market price as compared to pre IPO value estimates. They concluded that most appropriate valuations can be obtained by using multiples valuation based on post-IPO forecasted earnings and cash flows as compared to multiple valuations in the IPO year.

IPO firm's valuation obtains limited attention in the literature. Kim and Ritter (1999) elaborated how U.S firms offer prices are set in the market by using the multiples among recent IPOs from the same industry. They described that in valuation accuracy forward multiples of price earnings dominates the current price earnings multiples. The multiples valuation and discounted cash flow method also falls in the same field of accuracy of the valuation. Lie \& Lie (2002) described that discounted cash flow method perform at least as well as the multiples method in valuing leverage buyouts. They further elaborated that discounted cash flow valuation method and other valuation techniques are the similar results in the field of bankruptcy court cases.

Theoretical properties of several valuation frameworks have been studied by the valuation theorists. Penman (1998) elaborated the accuracy of the dividend, cash flow and accrual earnings equity value estimates. They described that values estimates focus on accrual earnings is more reliable than the estimates calculated from free cash flows.

\subsubsection{Valuation Model Choice}

It was argued by lot of authors that multi period valuation models based on discounted cash flows or residual income are best for single time period multiple valuation approaches, which shows less accuracy in valuation (Copeland, 2000). Empirical evidence on valuation models used by professional investors and financial analysts stands in contrast to the theoretical superiority of multi period valuation method.

\subsubsection{The Accuracy of Valuation Method}

Lot of studies examined the accuracy of valuation models. Few studies focused on multiple valuation method and provided the different results but multiple valuation method is the best for valuation accuracy 
It was compared by different researchers that choice of firms affects the accuracy of the valuation multiples. Profitability, growth and risk are the most important factors in peer group of selection and harmonic mean provides the best results (Kaplan and Ruback, 1995).

\section{Methodology}

\subsection{Selection of Valuation Method}

This section will develop the valuation model which will elaborate the choice for valuation methods regarding IPOs. This study proposes binary logit model to examine the determinants of the valuation methods.

\subsubsection{Size of Firms}

It is easier for larger firms to value rather than small firms because large firms forecast future cash flows and dividend in a better way as compared to the small firms (Ritter, 1984; Beatty and Ritter, 1986). This makes the possible use of dividend discount model and discounted cash flow method. We will measure the size (LnSIZE) of the firm by taking the natural log of the assets which are reported in the balance sheet of the company in the most recent financial year before taking the decision of going public.

\subsubsection{Log (1+age)}

The log of this variable (1+age) will be used as a proxy for risk. As it is said how much long the age of firm will lead the risk level as much lower (Ritter, 1984). He further described that calculation of future cash flows are so difficult and dividend for newly firms without preparing the previous track records as most of the time their values are represented by relying on future growth rates which varies from firm to firm. Forecasting of future cash flows and dividends is difficult for small size of firms.

\subsubsection{Assets of the Firm}

Accounting is a better way to capture the value of the firm's tangible assets as compared to the intangible assets. This increases the value of accounting methods such as the valuation methods. We will measure assets in place through the ratio of property, plant and equipment and all the total assets at the end of year preceding the IPO. In a common sense, accounting is considered to be a better way in capturing the value derived from tangible assets as compared to intangible assets.

\subsubsection{Firms Growth}

For proxy of growth opportunities, we employ the forecasted sale growth of the recent year. Short term free cash flows are negative for rapidly growing firms due to lower cash flows as compared to their capital investment. In discounted cash flow method, investment is loss of value and free cash flows fail to value the firm. Penman (2001) described that investment is considered as loss in dividend discounted cash flow method and freely cash flows totally fail to recognize the value that does not include the cash flows. In addition, highly growing firms keep their profits as savings rather than paying dividend.

\subsubsection{Dividend Payout}

Future dividend payouts will be disclosed through this ratio. High quality firms have better credibility as compared to the low quality firms. Bhattacharya (1979) showed that only high quality firms can use the dividend payout to show their quality to the investors. From their theoretical point of view, dividends are very costly and easily observable that low quality firms are unable to reproduce.

\subsubsection{Dividend Discount}

It is difficult for large firms to value firms because large part of their profit comes from growth options. Dividend discount model and discounted cash flow method cannot incorporate the value of these growth opportunities. Existing literature elaborate that many financial analysis view dividend discount model more useful to value stable, high dividend paying stock. They predict that underwriters most likely to use dividend discount model when setting the fair value estimates for firm. 


\subsubsection{Standard Deviation}

Rising aggregate stock market provides the great opportunities. For this purpose we will include this variable of market index return between 90 to 95 interval trading days five days before the $1^{\text {st }}$ day of IPO. Time period with high stock returns before IPO increases the usage of discounted cash flow method. Roosenboom (2007) included standard deviation of daily market index returns between 90 trading interval from 95 trading days before and 5 trading days before the IPO firms first day of trading into their model. They described that investors are mostly uncertain about the basic value when the overall market volatile. Underwriters may cater the investors demand to get more information about the basic value by valuing the IPO stock using direct valuation methods. Standard deviation of daily market index return will also be used between 90 to 95 days and 5 days before the $1^{\text {st }}$ day of IPO. Investors are unknown about the basic value when market is volatile.

\subsubsection{Underwriters Repute}

Underwriter reputation will be used as a control variable. Underwriter market share will be used as proxy. Underwriter market share will show the percentage of market share.

\section{Model :}

$$
\begin{gathered}
\text { Mult }_{i}=\beta_{0}+\beta_{1} \operatorname{lnsize}_{i}+\beta_{2} \ln \left(1+\text { Age }_{i}\right)+\beta_{3} A I P_{i}+\beta_{4} P R O F_{i}+\beta_{5} G_{R O W_{i}}+\beta_{6} D I V_{i}+\beta_{7} T E C H_{i} \\
+\beta_{8} \text { MRET }_{i}+\beta_{9} S D_{i}+\beta_{10} U R E P_{i}+\varepsilon_{i}
\end{gathered}
$$

MULT $_{\mathrm{i}}=1$ if underwriter uses Dividend Discount Model (DDM) and 0 otherwise, and so on for DCF, EVAi $_{i}, \mathrm{OTH}_{\mathbf{i}}$ separately as well.

Where

LnSIZE lnsize has calculated through natural logarithm of total asset in the balance sheet of most recent financial year before going public

$\operatorname{Ln}(\mathbf{1}+\mathbf{a g e}) \quad$ this has used as ex-ante proxy for risk.

AIP AIP has calculated through ratio of property plant and equipment and total asset at the end of the year

PROF PROF has calculated through price earnings multiples.

GROW calculated through forecasted sales growth

DIV calculated through dividend paid / total income

TECH calculated through technology level of companies

MRET calculated through discounted cash flow method.

SD calculated through standard deviation of daily market index return.

UREP calculated through underwriter market share.

\section{Results and Analysis}

This section will explain the results and analysis of descriptive statistics and regression models through various econometric techniques. E-views and SPSS software has been used to estimate results of these models.

\subsection{Descriptive Statistics}

This section will elaborate the descriptive statistics of variables used by the Binary Logit model.

Table 1: Descriptive Statistics of Variables used in Binary Logit Model

\begin{tabular}{|l|c|r|r|r|r|l|}
\hline & \multicolumn{1}{|c|}{ Mean } & \multicolumn{1}{c|}{ Median } & Maximum & Minimum & \multicolumn{1}{c|}{ St. Dev } & Observations \\
\hline SIZE & $39,316 \mathrm{ml}$ & $2,283 \mathrm{ml}$ & $718,943 \mathrm{ml}$ & $64 \mathrm{ml}$ & $1194 \mathrm{ml}$ & 80 \\
\hline
\end{tabular}




\begin{tabular}{|l|r|r|r|r|r|l|}
\hline & 13.0565 & 6.5000 & 66.0000 & 0.5000 & \multicolumn{1}{|l|}{15.6453} & \\
AGE & & & & & & \multicolumn{1}{l|}{} \\
\hline AIP & 19.9071 & 20.0686 & 25.1137 & 13.0347 & 2.6609 & 80 \\
\hline GROW & 63.7366 & 34.8250 & 640.7800 & -90.4300 & 104.7067 & 80 \\
\hline PROF & -3.1088 & 7.3632 & 347.0000 & -638.0000 & 114.5484 & 80 \\
\hline DIV & 9.4341 & 0.0000 & 89.5448 & 0.0000 & 21.6585 & 80 \\
\hline TECH & 0.5750 & 1.0000 & 1.0000 & 0.0000 & 0.4974 & 80 \\
\hline MRET & -0.0658 & -0.0900 & 0.7300 & -0.8000 & 0.2336 & 80 \\
\hline SD & 1.2475 & 1.1000 & 2.9600 & 0.5900 & 0.5224 & 80 \\
\hline UREP & 0.3375 & 0.0000 & 1.0000 & 0.0000 & 0.4758 & 80 \\
\hline
\end{tabular}

Table 1 elaborates the descriptive statistics of independent variables used in Binary Logit model. The size of the company plays a vital role for any IPO firm's evaluation. Size is measured through net turnover of IPOs firms before going public. The mean value of size is 39,316 million. The value of standard deviation is 1,194 million which represents the more volatility from their mean values. AGE defines that how much older the firm is. We measure company age as the number of years the firm has been in existence prior to its IPO. The mean value of these firms is 13 years. Property plant and equipment are very much important for any firm to get a high returns in the market. The average of AIP (20\%) defines that property plant and equipment are twenty percent of the total assets and it also indicates that firms are less capital intensive. The value of SD is 2.6 which represent the consistency of the Pakistani firms with respect to usages of more labor than automation involved in their business operations. Profitability also defines the firm's good position in the market and for dividend distribution of any firm. The results of descriptive statistics show that the profitability of the firms is in negative and few firms announced the dividend. The average $9 \%$ of dividend elaborate that few firms announced the dividend. Technology also plays the vital role for the evaluation of any firm. The mean value of technology is 0.57 . Most technological firms gain the higher return in the market as compare to the non technological firms. The value of SD is 0.49 which represents the less volatility of values from their mean values. Underwriter's reputation also plays a vital role to get the better returns in the market. The mean value of the UREP is 0.33 . The value of standard deviation is 0.47 which shows less volatility from their mean values. The market index return is measured during a 90 trading interval from 95 trading days before and 5 trading days before IPO firms $1^{\text {st }}$ day of trading. The average MRET is $-0.06 \%$. The market index volatility is measured as the standard deviation of daily market index return during the same 90 trading days' interval. The average SD equals 1.24.

\subsection{Multivariate Regression Models}

This section elaborates the regression results of Binary Logit Model by taking different valuation methods as dependent variable such as Dividend Discount Model (DDM), Discounted Cash flow method (DCF), Market/Peers Multiples (MULT), Economic Value Added (EVA) and OTHERS to estimate the final results of this binary logit regression model. E-views and SPSS have been used to estimate the results.

Table 2: BINARY LOGIT MODEL

\begin{tabular}{|c|c|c|c|c|c|c|c|}
\hline $\begin{array}{l}\text { Dependent } \\
\text { Var: }\end{array}$ & Multiples & & & Dependent Var: & DDM & & \\
\hline & Coefficient & t-statistic & Prob & & coefficient & t-statistic & prob \\
\hline $\mathbf{C}$ & 0.5344 & 1.2714 & 0.2079 & $\mathbf{C}$ & -0.7453 & -1.4991 & 0.1385 \\
\hline SIZE & 0.0281 & 0.6423 & 0.5228 & SIZE & 0.0964 & $* * 2.4616$ & 0.0164 \\
\hline $\mathbf{A G E}=$ & 0.2471 & $* * 2.1509$ & 0.035 & $\mathbf{A G E}$ & -0.0617 & -1.1211 & 0.2662 \\
\hline AIP & -0.0065 & -0.3205 & 0.7496 & AIP & 0.0005 & 0.0358 & 0.9715 \\
\hline GROW & -0.0005 & -0.914 & 0.3639 & GROW & -0.0001 & -0.3123 & 0.7558 \\
\hline
\end{tabular}




\begin{tabular}{|c|c|c|c|c|c|c|c|}
\hline PROF & 0.0003 & 0.5854 & 0.5602 & PROF & 5.56 & 0.231 & 0.818 \\
\hline DIV & 0.0002 & 0.1563 & 0.8762 & DIV & 0.0039 & $* * * 2.8793$ & 0.0053 \\
\hline ТЕСH & 0.0389 & 0.4904 & 0.6254 & TECH & -0.0155 & -0.2705 & 0.7875 \\
\hline MRET & -0.0749 & -0.3184 & 0.7511 & MRET & -0.1252 & -0.7075 & 0.4817 \\
\hline SD & 0.2795 & $* * 2.4644$ & 0.0163 & SD & -0.0091 & -0.1098 & 0.9128 \\
\hline UREP & -0.2454 & $* *-2.0173$ & 0.0476 & UREP & 0.0138 & 0.1548 & 0.8774 \\
\hline R-Square & 0.2695 & DW & 1.8657 & R-Square & 0.211 & DW & 1.6846 \\
\hline F-Statistics & 2.5092 & $\begin{array}{l}\text { Pro(F- } \\
\text { Statistics }\end{array}$ & 0.0124 & F-Statistics & 1.8905 & $\begin{array}{l}\text { Pro(F- } \\
\text { Statistics }\end{array}$ & 0.0736 \\
\hline \multirow[t]{2}{*}{$\begin{array}{l}\text { Dependent } \\
\text { Var: }\end{array}$} & \multicolumn{2}{|l|}{ DCF } & & \multirow[t]{2}{*}{ Dependent Var: } & OTHERS & & \\
\hline & Coefficient & t-statistic & Prob & & coefficient & t-statistic & prob \\
\hline $\mathbf{C}$ & -0.0482 & -0.2455 & 0.8068 & $\mathbf{C}$ & 0.2369 & 0.5915 & 0.5561 \\
\hline SIZE & -0.049 & $* *-2.3406$ & 0.0222 & SIZE & 0.0517 & 1.2117 & 0.2298 \\
\hline AGE_ & -0.0044 & -0.124 & 0.9016 & AGE_ & -0.08 & -1.0845 & 0.2819 \\
\hline AIP & 0.0065 & 0.6684 & 0.5061 & AIP & -0.008 & -0.403 & 0.6882 \\
\hline GROW & -0.0002 & -1.0655 & 0.2904 & GROW & 0.0014 & $* * 2.5598$ & 0.0127 \\
\hline PROF & 0.0002 & 1.3039 & 0.1967 & PROF & -0.0007 & $* *-2.0719$ & 0.0421 \\
\hline DIV & 0.0004 & 0.4555 & 0.6502 & DIV & -0.0009 & -0.5137 & 0.6091 \\
\hline ТЕСН & -0.0188 & -0.4947 & 0.6224 & TECH & -0.0864 & -1.1103 & 0.2708 \\
\hline MRET & 0.0581 & 0.5031 & 0.6165 & MRET & -0.2397 & -1.017 & 0.3127 \\
\hline SD & -0.0411 & -0.7599 & 0.4499 & SD & 0.1428 & $* * 2.2939$ & 0.0201 \\
\hline UREP & 0.1262 & $* * 2.1153$ & 0.0381 & UREP & 0.0935 & 0.7689 & 0.4446 \\
\hline R-Square & 0.1462 & DW & 2.1308 & R-Square & 0.2848 & DW & 1.7317 \\
\hline F-Statistics & 1.6247 & $\begin{array}{l}\text { Pro }(F- \\
\text { Statistics }\end{array}$ & 0.6687 & F-Statistics & 2.779 & $\begin{array}{l}\text { Pro }(F- \\
\text { Statistics }\end{array}$ & 0.0181 \\
\hline
\end{tabular}

\begin{tabular}{|l|r|r|r|}
\hline Dependent Var: & \multicolumn{2}{c}{ EVA } & \\
\hline Coefficient & \multicolumn{1}{c}{ t-statistic } & Prob \\
\hline SIZE & -0.0327 & -0.1655 & 0.8690 \\
\hline AGE_ & -0.0070 & -0.3384 & 0.7361 \\
\hline AIP & -0.0258 & -0.4752 & 0.6362 \\
\hline GROW & 5.9900 & 0.6290 & 0.5314 \\
\hline PROF & -3.0100 & -1.1192 & 0.2670 \\
\hline DIV & 9.1900 & 0.3684 & 0.7137 \\
\hline TECH & -0.0007 & -0.8140 & 0.4184 \\
\hline MRET & 0.0856 & $* * 2.2658$ & 0.0266 \\
\hline SD & -0.0398 & -0.3526 & 0.7254 \\
\hline UREP & -0.1138 & $* *-2.0692$ & 0.0423 \\
\hline R-Square & 0.0332 & 0.7684 & 0.4449 \\
\hline & 0.1377 & DW & 1.9151 \\
\hline
\end{tabular}




\begin{tabular}{l|r|c|c|} 
F-Statistics & 1.9863 & Pro(F-Statistics & 0.8849 \\
\hline * Significance at 10\% level, ** Significance at 5\% level, *** Significance at 1\% level
\end{tabular}

Table 2 represents the results of Binary Logit regression model. When MULT method used as a dependent variable, results reveal that AGE is significant at 5\% level as the value of t-statistics is 2.1509. Results depict that underwriters use peer multiples when firms are mature in age. Our results are consistent with Deloof et al (2009). SD is also measured as average returns of 60 days before going to formal listing in capital market. It is also significant at $5 \%$ level having t-statistic of 2.4644. Underwriters prefer to use multiples valuation method when market sentiments are bullish and stock prices are overvalued. UREP is also significant at 5\% level having the t statistics of -2.0173 . No literature supports the significance of UREP by using the multiple methods. Deloof et al (2009) explained the results by using the multiple method and described that SIZE is significant but our results are not consistent with them as SIZE is insignificant by using the multiple method. Deloof et al (2009) described that AIP is significant by using the MULT approach but our results are not consistent with them as AIP is not significant in our study by using the MULT approach. Deloof et al (2009) explained that PAYOUTS are significant by using the MULT approach but our results are showing the contradiction with them as PAYOUTS are not significant by using the MULT approach. Lie \& Lie (2002) used the MULT method and resulted that MTB is significant but our results show that MTB is not significant by using the MULT method. Keun (2006) explained that TECH is significant by using the MULT approach and in our results it is insignificant.

When we used DDM method as a depended variable, results show SIZE is significant with the t-value of 2.4616 at 5\% level. Results urged that underwriters prefer to use Dividend Discount model for big firms in term of total assets. Our results are consistent with Deloof et al, (2009). DIV is significant with the tvalue of 2.8793 at $1 \%$ level. DIV shows the worth of the firms which regularly issue the dividends. No literature support our results at the significance of DIV. Deloof et al (2009) used the DDM model and explained that AGE is significant but our results are not consistent with them as AGE is not significant in our study by using the DDM approach. Deloof et al (2009) used the DDM model and revealed that AIP, GROW and PAYOUTS are significant but our results are insignificant. Penman (1998) elaborated that MTB is significant by using the DDM approach but our results are insignificant in our study. SD, MRET and UREP are also insignificant in our study.

In our results SIZE and UREP are significant at 5\% level with the t-values of -2.3406 and 2.1153 respectively. Yee (2002) used the DCF method for evaluation and resulted that SIZE is significant and our results are also consistent with them. He also explained the results by using the DCF method and revealed that TECH is significant but our results revealed that TECH is insignificant by using the DCF method. Yee (2002) used the DCF method and resulted that UREP is significant and our results are also consistent with them as UREP is significant at $5 \%$ level by using the DCF approach. Remaining variables AIP, GROW, DIV, SD, MRET AGE are insignificant in our study by using the DCF approach. It was also found that underwriters use the discounted cash flow analysis when market index returns (MRET) are high. This market condition offer a window of opportunity in which investors want to get the more stocks and willing to get more cash flow and assumptions of discount rate underlying the discounted cash flow method. Table 2 report that the volatility of market index (SD) is negatively related to use of discounted cash flow model. In this situation of the market the investors are uncertain about the basic value. We do not found that underwriter use the discounted cash flow model mostly when value large firms (size), older companies (Ln (1+age)) with lower growth rates (Grow).

In our study GROW; SD and PROF are significant at 5\% level with the t-values of 2.5598, 2.2939 and 2.0719 respectively by using the OTHERS approach. By grow we mean at what rate the sales are increasing of the firm. No existing literature supports our results. Bancel (2004) described that MTB and Size are significant by using the OTHERS approach. Other variables SIZE, AGE, TECH, SD, MRET, AIP and UREP are insignificant in our study by using the OTHERS approach. In our study the TECH is 
significant at $5 \%$ level with the t-value of 2.2658 and SD is significant at $5 \%$ level with the t-value of 2.0692 .

By using the EVA as a dependent variable TECH and SD are significant at 5\% level in our study. No literature support our results at the significance of TECH and SD. Yee (2002) used the EVA approach and resulted that AGE is significant but our results are against them as AGE is insignificant. Other variables AGE, AIP.UREP, MRET and PROF are insignificant in our study by using the EVA approach and results are consistent with them.

\section{Summary and Conclusion}

The literature about the valuation of firms is particularly shorter to about that how underwriters value the shares of those firms which go public. The major purpose of our study is to fill up this gap. We got the valuation report from different underwriters that give us access to make an analysis for the sample of 80 IPOs from the period of 2000-2015. The purpose of our study is to answer the three research questions.(i) How does underwriter lay down the preliminary offer price by using different valuation methods?.(ii) How underwriters check the accuracy and authenticity of the different valuation methods. (iii) Does underwriter meet the ambition of issuer firm to achieve the highest value while ensuring an optimistic start of secondary trading and short run after market performance?

It was documented that underwriters mostly use the multiple valuation method, dividend discount model, discounted cash flow method to value the IPO firms. Economic value added method has less usage by underwriters to value the equity of the IPO firms. Results depict that underwriters use multiple methods for the valuation of older firms when their firms are underwritten by reputed underwriters. Dividend discount model is suitable to value the firms which are highly profitable and firms which regularly issue the large part of their earnings as dividends. Discounted cash flow method is suitable for the large size firms and highly reputable underwriters. Economic valuation method is used by the underwriters to value the firms which are technologically advanced firms and those firms which have the high returns in the market. Others approach is used by the underwriters for those firms which are highly profitable.

\section{Refrences}

Agathee S.U., (2006), Day of the week effects: Evidence from the stock exchange of Mauritius (SEM)\|, International research journal of Finance and Economics.

Allen, F., \& Faulhaber, G. R. (1989). Signaling by under pricing in the IPO market. Journal of financial Economics, 23(2), 303-323.

Afza, T., Yousaf, H., \& Alam, A., (2013). Information asymmetry, corporate governance and IPO underpricing. Science International, 25(4).

Bayar A., \& Kan B.O., (2002). Day of the week effects: Recent evidence from nineteen stock markets\|. Central Bank Review.

Bhattacharya, S. (1979). Imperfect Information, Dividend Policy, and "The Bird in the Hand" Fallacy. The Bell Journal of Economics, 10, 259-270.

Beatty, R. P., \& Ritter, J. R. (1986). Investment banking, reputation and the under pricing of initial public offerings. Journal of Financial Economics, 15 (1), 213 - 232.

Bancel, F., \& Mittoo, U. R. (2009). Why do European firms go public?. European Financial Management, 15(4), 844-884. 
Cheng, C. A., \& McNamara, R. (2000). The valuation accuracy of the price-earnings and price-book benchmark valuation methods. Review of Quantitative Finance and Accounting, 15(4), 349-370.

Copeland, T., T. Koller and J. Murrin (2000). Valuation, measuring and meaning the values of companies (Mckinsey and company., Inc. New York, NY: John Wiley \& Sons).

Deloof, M., De Maeseneire, W., \& Inghelbrecht, K. (2009). How do investment banks value initial public offerings (IPOs)?. Journal of Business Finance \& Accounting, 36 (1 - 2), 130 - 160

Demirakos, E. G., Strong, N. C., \& Walker, M. (2004). What valuation models do analysts use? Accounting horizons, 18(4), 221-240.

Engelen, P. J., \& Van Essen, M. (2010). Under pricing of IPOs: Firm-, issue-and country-specific characteristics. Journal of Banking \& Finance, 34(8), 1958-1969.

Francis, J., P. Olsson and D. Oswald, (2000), "Comparing the Accuracy and Explainability of Dividend, Free Cash Flow, and Abnormal Earnings Equity Value Estimates”, Journal of Accounting Research 38, 45-70.

Kim, M., \& Ritter, J.R. (1999). Valuing IPOs. Journal of Financial Economics, 53(3), 409 - 437.

Kaplan, S.N., and R. Ruback. 1995. "The Valuation of Cash Flow Forecasts: An Empirical Analysis." Journal of Finance, vol. 50, no. 4 (September):1059-93.

Keun Yoo, Y. (2006). The valuation accuracy of equity valuation using a combination of multiples. Review of Accounting and Finance, 5(2), 108 - 123.

Lie, E., \& Lie, H.J. (2002). Multiples used to estimate the corporate value. Financial Analysts Journal.1 10.

Pagano, M., Panetta, F., \& Zingales, L. (1998). Why do companies go public? An empirical analysis. The Journal of Finance, 53(1), 27-64.

Penman, S. H. (1998). A synthesis of equity valuation techniques and the terminal value calculation for the dividend discount model. Review of Accounting Studies, 2 (4), 303 - 323.

Penman, S. H. (2001). Financial statement analysis and security valuation. New York, NY: McGrawHill/Irwin.

Roosenboom, P. (2007). How do underwriters value initial public offerings? An empirical analysis of the French IPO market. Contemporary Accounting Research, 24(4), 1217-1243.

Rock, K. (1986). Why new issues are underpriced. Journal of financial economics, 15(1-2), 187 - 212.

Ritter, J. R. (1991). The long run performance of initial public offerings. The journal of finance, 46(1), 3-27.

Rizwan, M. F., \& Khan, S. U. (2007). Long-run performance of public vs. private sector initial public offerings in Pakistan. The Pakistan Development Review, 421 - 433.

Sadaqat, M. S., Akhtar, M. F., \& Ali, K. (2011). An analysis on the performance of IPO - a study on the Karachi Stock Exchange of Pakistan. International Journal of Business and Social Science, 2(6), 
275-285.

Sohail, M. K., \& Nasr, M. (2007). Performance of initial public offerings in Pakistan. International Review of Business Research Papers, 3(2), 420 - 441.

Welch, I. (1989). Seasoned offerings, imitation costs, and the under pricing of initial public offerings. The Journal of Finance, 44(2), 421-449.

Yee, K. (2002). Judicial valuation and the rise of DCF. Public Fund Dig, 76, 76 - 84. 